\title{
Metode Diskusi Lembaga Kajian dan Pengembangan Sumberdaya Manusia Nahdlatul Ulama
}

\author{
Agi M. Abdul Ghani \\ UIN Sunan Gunung Djati Bandung, Indonesia \\ Email: agimaghani@gmail.com
}

\begin{abstract}
Disadvantaged, Outermost and Frontier Regions (3T) are the country's strategic areas that must be considered. Given the many issues and problems that occur in the 3T Region, ranging from moral crises, morals, to the crisis of nationalism. The main factor causing these problems is due to geographical, sociological and cultural factors that develop in the 3T Region. This condition certainly has an impact on aspects of community development, including religious social counseling activities. Aims to study in depth and describe the Communication Patterns of Islamic Religious Instructors in the 3T Region of Sajingan Besar District, Sambas Regency in accordance with their main duties and functions, namely Informative, Educational, Consultative and Advocative functions. As for answering the two concepts, the theory used is the theory of information direction and the theory of attribution (subjectivity) in the counseling process to the community in the 3T Region of Sajingan Besar District. The research paradigm used is naturalistic with a phenomenological approach, a type of qualitative research with a case study method. The results of the study based on the objectives and focus of the problem can be concluded that the Communication Patterns of Islamic Religious Instructors in carrying out the main function of counseling to the community in the 3T Region of Sajingan Besar District are both informative, educative, consultative and advocative functions.
\end{abstract}

Keywords: 3T, Communication, Sambas

\begin{abstract}
ABSTRAK
Kegiatan diskusi merupakan suatu metode dakwah yang tercantum dalam al-Qur'an yang selama ini cenderung kurang populer. Lakpesdam NU adalah perangkat ormas NU yang berfungsi sebagai lembaga kajian isu-isu strategis dan pemberdayaan manusia untuk transformasi sosial yang berkeadilan dan bermartabat. Metode kajian diskusi Lakpesdam PCNU kota Tasikmalaya terkait dengan keislaman, menekankan aspek rasionalitas, argumentasi, dan aspek penunjang diskusi lainnya. Pendekatan terhadap masalah diatas menggunakan pendekatan teori metode dakwah diskusi dengan jenis penelitian kualitatif yaitu menggunakan paradigma interpretif. Teknik pengumpulan data dalam penelitian ini menggunakan teknik observasi, wawancara mendalam, dan dokumentasi. Adapun analisis data yang dilakukan dalam penelitian ini dilakukan dengan beberapa tahap, yakni tahap identifikasi data, kategorisasi data, reduksi data, seleksi data, analisis data, dan penarikan kesimpulan. Hasil penelitian menunjukkan bahwa, teknis kegiatan diskusi yang dilakukan oleh Lakpesdam PCNU kota Tasikmalaya dilakukan secara bebas dan santai, namun tetap pada koridor pertukaran pemikiran yang serius, serta berjalan secara demokratis. Orang-orang yang terlibat dalam kegiatan diskusi tersebut, mengemukakan pendapatnya secara argumentatif dengan menggunakan buku-buku kontemporer ataupun kitab-kitab klasik.
\end{abstract}

Kata Kunci: Dakwah, Sumberdaya dan Lakpesdam

\section{PENDAHULUAN}

Dakwah merupakan seruan kepada nilai-nilai kebaikan, khususnya nilai-nilai keislaman. Menurut Muhammad Al-Bahby dakwah merupakan perubahan suatu situasi ke situasi yang lebih baik sesuai dengan ajaran Islam.(Rahman, 2010) Pada dasarnya pola dakwah tidak jauh berbeda dengan pola 
komunikasi yaitu da'i - pesan - uslub - media - mad'u. kegiatan dakwah juga tidak menuntut mad'u yang banyak, atau dilakukan di ruang terbuka, seperti kegiatan ceramah, Khutbah 'id, dan lain sebagainya.

Mayoritas kegiatan dakwah didaerah perkotaan sering dilakukan diatas mimbar pada saat momenmomen tertentu seperti saat khutbah jumat atau peringatan hari-hari besar Islam (PHBI). Namun, tidak jarang pula orang menggunakan media lain seperti media tulis atau media elektronik. Selain terikat pada waktu dan media tertentu, kegiatan dakwah juga seringkali terikat oleh ruang-ruang formal seperti pesantren, sekolah agama, masjid, madrasah, majelis ta'lim, kelas-kelas perkuliahan, dan lain sebagainya. Selain itu, dalam kegiatan dakwah yang banyak terjadi, seringkali menerapkan sistem komunikasi satu arah, yang mana seorang da'i merupakan satu-satunya sumber kebenaran bagi para mad'unya, sehingga bentuk dakwah yang terjadi dewasa ini hanya merupakan gerakan doktrin semata, tanpa adanya upaya untuk mendewasakan pola pikir masyarakat.

Oleh karena fenomena-fenomena dalam mayoritas kegiatan dakwah itulah yang membuat kegiatan dakwah terlihat eksklusif, serta mengakibatkan kegiatan dakwah kurang dapat menjangkau beberapa lapisan masyarakat tertentu. Selain itu, pesan-pesan dakwah yang disampaikan oleh para da'i pun selalu terpenjara oleh momen yang sedang berlangsung, seperti pada kegiatan dakwah dalam rangka memperingati Maulid Nabi, sudah barang tentu sang Da'i akan menyajikan materi dakwahnya seputar peristiwa kelahiran Nabi Saw. atau hanya ditambah sedikit-sedikit dengan analisis dan sudut pandang yang berbeda dari da'i lainnya. Sedangkan yang dibutuhkan oleh mad'u bukan hanya mendengarkan kisah-kisah gemilang perjuangan Rasul, bukan hanya cerita-cerita ajaib tentang kelahiran Muhammad, melainkan mereka juga butuh ilmu yang bisa mendewasakan pola pikir mereka sendiri. Sebagai contoh, seorang da'i sudah tidak perlu lagi mengajarkan mad'unya tentang produk-produk fiqih, seperti daging babi itu haram, berjudi pun haram, atau shalat itu wajib, akan tetapi seharusnya seorang da'i memberikan pesan dakwah ushul fiqih yang bisa mendewasakan pola pikir mad'unya, agar seorang mad'u tidak lagi harus bertanya bagaimana hukumnya berjudi, bagai mana hukumnya shalat, dan lain sebagainya.

Kegiatan dakwah dari mimbar-kemimbar sejatinya hanya menyebarkan doktrin-doktrin yang dipahami oleh sang da'i. Selain itu, aktivitas dakwah via mimbar juga menciptakan kesenjangan antara seorang da'i dengan mad'unya, dikarenakan ada semacam jarak yang terbentuk oleh adanya gelar da'i bagi sang Komunikator, dan gelar mad'u bagi sang Komunikan.

Ilyas Ismail berpendapat bahwa mad'u merupakan sentral utama kegiatan dakwah. Oleh karena itu, dakwah seharusnya berorientasi pada keinginan mad'u, bukan berorientasi pada keinginan da'i.(Basit, 2013) Maka dari itu kegiatan dakwah mesti berorientasi pada keinginan atau kebutuhan mad'u. Seorang da'i mesti memahami setidaknya tiga aspek dari mad'u tersebut; pertama, aspek intelektual mad'u. Kedua, kondisi psikologis mad'u. Ketiga, problem kekinian yang dihadapi oleh mad'u.(Hotman, 2011) Untuk memahami tiga aspek tersebut, seorang da'i yang melakukan kegiatan dakwah hanya melalui mimbar jelas mustahil memahaminya. Setidaknya jika seorang da'i ingin memahami tiga aspek mad'u sebagaimana disebutkan, da'i tersebut mesti melakukan observasi terlebih dahulu pada kondisi objektiv mad'u. Hal itu jelas tidak mungkin dilakukan oleh da'i yang melakukan kegiatan dakwah melalui mimbar, mengingat mayoritas dari mereka hanya datang saat diundang, dan hanya datang saat hari $\mathrm{H}$ telah tiba.

Lain halnya dengan kelompok diskusi dimana mereka bisa saling memahami antara satu dengan yang lainnya. Setidaknya jika da'i dan mad'u sering malakukan kontak komunikasi, mereka akan lebih mengenal dan memahami kondisi psikologis yang dialami, kapasitas intelektual yang dimiliki, serta masalah yang sedang dihadapi. Dengan demikian, kegiatan dakwah melalui kelompok diskusi ini bisa lebih berorientasi kepada kebutuhan mad'u, dari pada keinginan da'i. 
Pada tataran praktisnya, kegiatan dakwah dapat dilakukan melalui diskusi-diskusi ringan atau obrolan-obrolan santai, asalkan pesan dakwah tetap tersampaikan dengan baik, karena hakikat dari kegiatan dakwah adalah tersampaikannya suatu pesan dakwah dari seorang da'i kepada mad'unya. Kegiatan dakwah tidak mesti harus melalui mimbar belaka. Seperti halnyayang dilakukan oleh Rasul Saw., pada dakwah sembunyi-sembunyinya beliau tidak melakukan dakwah diatas mimbar, melainkan melalui meja makan.(Al-Mubarakfury, 2013) Dalam pelaksanaanya, kegiatan dakwah dapat dilakukan dimanapun dan kapanpun, baik itu tempat formal seperti sekolah, kantor, kampus, maupun tempat non-formal seperti: masjid, pesantren, dan tempat-tempat lainya.

Lembaga Kajian dan Pengembangan Sumberdaya Manusia Nahdlatul Ulama (Lakpesdam NU). adalah perangkat ormas $\mathrm{NU}$ yang berfungsi sebagai lembaga kajian isu-isu strategis dan pemberdayaan manusia untuk transformasi sosial yang berkeadilan dan bermartabat. Terdapat beberapa kegiatan yang dilakukan di Lakpesdam NU, yakni melakukan kajian isu-isu strategis kebangsaan dan keislaman, melakukan advokasi kebijakan publik dasar, khususnya terkait pendidikan, kesehatan, ekonomi, dan sosial, memberikan dukungan data, analisis, argumentasi, dan alternatif rumusan kepada NU dalam perumusan sikap dan kebijakan organisasi. Mengarusutamakan pelaksanaan nilai-nilai Islam ahlu sunnah waljama'ah an-nahdhiyah yang moderat, toleran, mengakui dan menghargai keragaman, ramah dan berkeadilan (Islam Nusantara), mendinamisasi pemberdayaan manusia, memfasilitasi kaderisasi di lingkungan $\mathrm{NU}$, mengelola pengetahuan dan sumber-sumbernya agar memberikan manfaat dalam pemberdayaan manusia dan pengembangan ilmu.

Lakpesadam NU tersebar sesuai dengan tingkatan-tingkatan NU, dari mulai Pengurus Besar (pusat), hingga Pengurus Cabang (tingkat kabupaten/kota), tak terkecuali Pengurus Cabang Nahdlatul Ulama (PCNU) Kota Tasikmalaya. Lakpesdam PCNU Tasikmalaya beralamat di Jl. Paseh Selaawi Kec. Mangkubumi Kota Tasikmalaya. Pada kegiatannya, Lakpesdam PCNU Tasikmalaya sejalan dengan apa yang telah menjadi tugasnya sebagai organisasi pembantu NU. Dibidang pemberdayaan manusia, Lakpesdam PCNU Tasikmalaya banyak melakukan program pelatihan, seperti pelatihan kelompok tani, hingga pelatihan kader perdamaian. Sedangkan dalam bidang kajian, Lakpesdam PCNU Tasikmalaya banyak melakukan perdiskusian, baik dalam lingkup internal, maupun dalam lingkup yang lebih luas dengan melibatkan masyarakat Tasikmalaya.

Dalam prakteknya, kegiatan diskusi yang dilakukan oleh Lakpesdam PCNU kota Tasikmalaya, banyak dihadiri oleh ormas-ormas kemahasiswaan, seperti Hima (Himpunan Mahasiswa) Persis, Ikatan Mahasiswa Muhammadiyah (IMM), Pergerakan Mahasiswa Islam Indonesia (PMII), Himpunan Mahasiswa Islam (HMI), dan lain sebagainya. Fokus kajian materi-materi yang didiskusikan oleh Lakpesdam PCNU kota Tasikmalaya adalah materi tentang kajian keislaman.

Materi-materi yang dibahas oleh Lakpesdam PCNU kota Tasikmalaya, tercermin dari hasil diskusidiskusi mereka, yang mengarah pada pemahaman Islam. Dewasa ini pemahaman Islam melalui kegiatan diskusi seolah menjadi barang langka, mengingat begitu maraknya para da'i yang menyebarkan pesan dakwah yang berupa doktrin-doktrin. Pemahaman ini tidak bisa dipungkiri, telah merambah berbagai lapisan masyarakat. Hal ini dapat dibuktikan dengan maraknya orang-orang yang berpakaian layaknya orang Arab (bergamis, berjanggut, bercelana cingkrang, dan sebagainya) dengan dalih, pakaian seperti itu adalah pakaian Sunnah, padahal memeluk agama Islam bukan berarti harus menyerupai orang Arab.

Kegiatan diskusi merupakan suatu metode dakwah yang tercantum dalam al-Qur'an yang selama ini cenderung kurang populer. Padahal, melalui diskusi, kegiatan dakwah akan menjadi lebih hidup, serta pesan dakwah akan lebih dapat dipahami secara lebih mendalam. Pada hakikatnya, kegiatan diskusi 
merupakan aktivitas pertukaran pendapat yang terjadi diantara beberapa orang secara lisan, membahas permasalahan tertentu dengan teratur, guna mencari sebuah kebenaran.

Mengkaji tentang metode kajian diskusi Lakpesdam PCNU kota Tasikmalaya terkait dengan keislaman, bisa menjadi salah satu model pengembangan dakwah melalui pendekatan ilmiah, sebab yang ditekankan dalam kegiatan diskusi Lakpesdam PCNU kota Tasikmalaya adalah aspek rasionalitas, argumentasi, dan aspek penunjang diskusi lainnya. Hal ini sangat jarang terjadi mengingat kegiatan dakwah melalui kegiatan ceramah pada umumnya hanya mengedepankan aspek oral atau retorika belaka.

Fenomena tentang perdiskusian Lakpesdam PCNU kota Tasikmalaya ini menjadi sangat menarik untuk diteliti, terutama pada aspek metode dakwah yang dilakukan oleh Lakpesdam PCNU kota Tasikmalaya. Oleh karena itu, yang menjadi fokus dalam penelitian ini adalah metode dakwah Lakpesdam PCNU kota Tasikmalaya.(Aziz, 2012).

\section{METODE PENELITIAN}

Metode yang digunakan dalam penelitian ini adalah kualitatif.(Sadiah, 2015) Metode ini digunakan untuk merumuskan metode dakwah (Munir, 2015) dari perdiskusian yang dilakukan oleh Lakpesdam PCNU Tasikmalaya. Artinya, metode(Ardianto, 2010) ini diusahakan untuk melukiskan dan memaparkan data yang ada secara lebih sederhana berupa kata-kata tertulis atau lisan dari sejumlah orang atau perilaku yang dapat dicermati. Metode ini disesuaikan dengan tujuan penelitian yang hendak dicapai, yaitu dapat memberikan wawasan baru tentang teori-teori metode dakwah.(Morissan, n.d.)

Adapun pengumpulan data dalam penelitian ini, menggunakan beberapa teknik yang bisa digunakan dalam penelitian, guna memperoleh data atau informasi secara nyata serta mendalam mengenai aspek-aspek yang penting dan menonjol. Maka teknik pengumpulan data yang digunakan dalam penelitian ini berupa observasi, wawancara, dan dokumentasi.(Moleong, 2012)

\section{HASIL DAN PEMBAHASAN}

\section{Proses Pertukaran Pemikiran yang Terjadi dalam kegiatan diskusi di Lakpesdam PCNU kota Tasikmalaya}

kegiatan diskusi yang dilakukan oleh Lakpesdam PCNU kota Tasikmalaya, terbagi menjadi dua bagian, yakni diskusi rutin dan diskusi umum. Dalam kegiatan diskusi umum, Lakpesdam PCNU kota Tasikmalaya bekerja sama dengan The Wahid Institute, melakukan kegiatan diskusi dengan tema-tema yang ditentukan oleh The Wahid Institute, yakni tentang kebangsaan, pluralisme, kebhinekaan, kebangsaan, dan toleransi. Kegiatan diskusi umum ini hanya dilakukan saat ada kontrak kerjasama dengan The Wahid Institute.

Program kajian diskusi umum ini, biasanya diselenggarakan di perguruan-perguruan tinggi yang ada di kabupaten/kota Tasikmalaya. Sesuai kesepakatan dengan The Wahid Institute, program kajian diskusi umum ini menjadikan kaum muda, khususnya mahasiswa, sebagai sasaran utama.

Teknis kegiatan diskusi umum Lakpesdam PCNU kota Tasikmalaya berlangsung sama, yakni berlangsung dengan tidak formal, karena dalam kegiatan diskusi tersebut seringkali diselingi humor jenaka dari narasumber. Bahkan, pada kegiatan diskusi umum yang diadakan dikampus tertentu, seperti di kampus STAI, beberapa narasumber bisa merokok sambil memberikan materi diskusi. Lain halnya dengan di UPI Tasikmalaya, dimana sebelum program kajian diskusi ini berlangsung, antara pihak penyelenggara (Lakpesdam PCNU kota Tasikmalaya dan The Wahid Institute) dan pihak fasilitator (UPI Tasikmalaya), menyepakati beberapa MOU yang diantaranya tidak boleh merokok di ruangan tempat 
acara berlangsung. Meski demikian, kegiatan diskusi umum Lakpesdam PCNU kota Tasikmalaya ini tetap tidak kehilangan inti dari kegiatan diskusi tersebut, yakni proses pertukaran pemikiran.

Kendati kegiatan diskusi umum ini berjalan dengan tidak formal, tetap saja ada beberapa peraturan yang mesti dipatuhi oleh seluruh peserta diskusi, seperti tidak membuat bising ruangan diskusi saat narasumber sedang memberikan materi, tidak membuat forum didalam forum, tidak memotong pembicaraan narasumber, peserta diskusi hanya boleh mengajukan pertanyaan atau mengemukakan pendapatnya pada sesi tanya-jawab, mesti menghargai moderator sebagai pimpinan diskusi dan lain sebagainya.

Selanjutnya, pada tataran praktisnya, saat kegiatan diskusi berlangsung, para narasumber duduk di belakang meja yang disediakan di bagian depan ruangan aula. Sedangkan peserta diskusi duduk rapi berjejer menghadap arah berlawanan dengan para narasumber. Kegiatan diskusi tersebut dipimpin oleh seorang moderator yang duduk berdampingan dengan para narasumber. Kegiatan tanya-jawab serta saling tukar pendapat pun terjadi antara peserta dan narasumber, mengingat peserta diskusi yang mengikuti kegiatan kajian diskusi umum ini tidak hanya dihadiri oleh mahasiswa, namun juga dihadiri oleh para dosen dan staf.

Kegiatan diskusi umum yang dilakukan oleh Lakpesdam PCNU kota Tasikmalaya ini sejalan dengan teori diskusi panel yang dikemukakan oleh Harold Zelko. Dalam teorinya, Zelko mengatakan bahwa diskusi panel merupakan kegiatan diskusi yang mana pesertanya diatur oleh peraturan yang sebelumnya telah disepakati. Dalam diskusi panel ini, terdapat beberapa orang yang menjadi pembicara pokok (panelis). Para panelis ini masing-masing akan berbicara tentang masalah yang sama, namun dengan sudut pandang keahlian masing-masing panelis yang berbeda.

Dalam kegiatan diskusi panel, biasanya peserta diskusi duduk menghadap meja yang disimpan didepan ruangan pertemuan, dimana moderator dan para panelis duduk dibalik meja tersebut, berhadapan dengan peserta diskusi. Kegiatan pertukaran pendapat dalam diskusi panel, biasanya berlangsung secara informal, bahkan sering kali terjadi tanpa persiapan sama sekali, meskipun kegiatan tersebut berlangsung sesuai dengan peraturan yang disepakati sebelumnya .

Melihat teori yang dikemukakan oleh Zelko ini, maka diskusi umum yang dilakukan oleh Lakpesdam PCNU kota Tasikmalaya di berbagai kampus, dapat dikategorikan sebagai diskusi panel, yang sejalan dengan teorinya. Dalam teori tersebut, setidaknya ada empat indikator yang membuat sebuah kegiatan pertukaran pemikiran disebut sebagai diskusi panel. Pertama, narasumber dalam diskusi tersebut berjumlah lebih dari satu orang. Kedua, ada peraturan yang disepakati, yang mengikat seluruh peserta diskusi. Ketiga, dalam teknis pelaksanaan diskusi panel, narasumber dan moderator duduk berdampingan, serta berhadap-hadapan dengan para peserta diskusi. Keempat, meski terikat oleh peraturan tertentu, kegiatan diskusi panel tetap berjalan secara informal.

Keempat indikator diskusi panel tersebut, semuanya terpenuhi dalam kegiatan diskusi umum yang dilakukan oleh Lakpesdam PCNU kota Tasikmalaya. Pertama, dalam diskusi umumnya, Lakpesdam PCNU kota Tasikmalaya menyediakan beberapa narasumber dari bidang keilmuan yang berbeda. Narasumber tersebut biasanya diisi oleh pihak Lakpesdam PCNU kota Tasikmalaya sendiri, dari pihak The Wahid Institute, dan dari dosen-dosen atau guru besar pihak kampus yang bertindak sebagai tuan rumah. Dalam sekali diskusi umum yang diadakan oleh Lakpesdam PCNU kota Tasikmalaya, sedikitnya selalu terdapat tiga orang narasumber dari tiga institusi berbeda (Lakpesdam PCNU kota Tasikmalaya, The Wahid Institute, dan pihak kampus), bahkan bisa mencapai lima orang narasumber.

Kedua, terdapat peraturan yang disepakati untuk mengikat seluruh peserta diskusi. Indikator ini pun terkandung dalam kegiatan diskusi umum yang dilakukan oleh Lakpesdam PCNU kota Tasikmalaya. 
Dalam kegiatan diskusi umumnya, selalu ada peraturan yang disepakati, oleh pihak Lakpesdam PCNU kota Tasikmalaya dan pihak kampus sebagai fasilitator. Seperti tidak membuat bising ruangan diskusi saat narasumber sedang memberikan materi, tidak membuat forum didalam forum, tidak memotong pembicaraan narasumber, peserta diskusi hanya boleh mengajukan pertanyaan atau mengemukakan pendapatnya pada sesi tanya-jawab, mesti menghargai moderator sebagai pimpinan diskusi dan lain sebagainya. Bahkan dalam kegiatan diskusi umum yang diselenggarakan di kampus UPI kota Tasikmalaya, narasumber mesti mematuhi peraturan untuk tidak merokok di ruangan diskusi. Peraturan-peraturan tersebut dibuat demi kelancaran dan ketertiban kegiatan diskusi yang berlangsung.

Ketiga, indikator yang membuat sebuah kegiatan pertukaran pemikiran dikatakan sebagai diskusi panel, adalah pada tataran pelaksanaannya, peserta diskusi duduk menghadap meja yang disimpan didepan ruangan pertemuan, dimana moderator dan para panelis duduk dibalik meja tersebut, berhadapan dengan peserta diskusi. Teknis diskusi ini pun dipenuhi oleh kegatan diskusi rutin Lakpesdam PCNU kota Tasikmalaya. Dalam kegiatan diskusi umum tersebut, para narasumber duduk dibelakang meja yang disediakan dibagian depan ruangan aula. Sedangkan peserta diskusi duduk rapi berjejer menghadap arah berlawanan dengan para narasumber. Kegiatan diskusi tersebut dipimpin oleh seorang moderator yang duduk berdampingan dengan para narasumber.

Indikator terakhir yang ada pada teori diskusi panel yang dikemukakan oleh Zelko, yakni kegiatan diskusi tersebut berlangsung secara tidak formal. Hal ini juga terdapat dalam kegiatan diskusi umum yang dilakukan oleh Lakpesdam PCNU kota Tasikmalaya, dimana kegiatan pertukaran pemikirannya berlangsung secara tidak formal. Dalam kegiatan diskusi umum ini, seringkali diselingi humor-humor jenaka yang tak jarang mengundang gelak tawa seluruh peserta diskusi. Selain itu, kepulan asapa rokok dari para narasumber pun, sudah menunjukkan bahwa kegiatan diskusi tersebut berlangsung secara tidak formal. Bahkan dikampus-kampus tertentu, seperti STAI kota Tasikmalaya, tidak hanya narasumber yang merokok, melainkan segelintir peserta diskusi pun ikut merokok.

Selain kegiatan diskusi umum yang bekerjasama dengan The Wahid Institute, adapula kegiatan diskusi rutin yang merupakan program murni dari Lakpesdam PCNU kota Tasikmalaya, tanpa adanya kerjasama dengan pihak-pihak lain. Kegiatan kajian diskusi rutin ini diselenggarakan secara intens di gedung kantor Lakpesdam PCNU kota Tasikmalaya, dengan mengundang berbagai ormas keagamaan. Adanya program kajian diskusi rutin ini, disambut antusias oleh organisasi-organisasi masyarakat, khususnya organisasi berbasis kemahasiswaan.

Teknis diskusi pada kegiatan program kajian diskusi rutin Lakpesdam PCNU kota Tasikmalaya, berlangsung secara tidak formal. Dikatakan seperti itu, karena dalam kegiatan diskusinya, seluruh peserta diskusi bebas untuk merokok, makan makanan yang telah disediakan oleh panitia, serta selalu sedikit diselingi dengan humor-humor yang tak jarang mengundang gelak tawa seluruh peserta diskusi. Kendati demikian, kegiatan kajian diskusi rutin Lakpesdam PCNU kota Tasikmalaya tetap tidak kehilangan kekhidmat-annya (kegiatan diskusi dilakukan dengan cara serius tapi santai). Narasumber didampingi oleh seorang moderator dan terkadang ada narasumber dua yang bertindak sebagai pembanding, duduk menghadap peserta diskusi yang telah duduk melingkar. Tidak ada kursi dan meja yang tersedia, sebagaimana kajian diskusi umum. Kegiatan kajian diskusi rutin ini dilakukan dengan duduk lesehan, hingga menimbulkan kesan yang lebih santai.

Melihat teknis kegiatan diskusi rutin yang diselenggarakan oleh Lakpesdam PCNU kota Tasikmalaya ini, tidak ada teori diskusi yang sejalan dengan teknis pelaksanaannya. Hal tersebut dapat dibuktikan dari beberapa teori diskusi yang ada seperti, teori diskusi kelompok, forum, diskusi panel, simposium, seminar, pro-kontra, rembuk sejati, cawan ikan, kotak surat masuk, momentum, urun 
pendapat, buszz group, pemeranan, dan foto novellas. Dari teori-teori diskusi tersebut, tidak ada satu teori pun yang sejalan dengan teknis pelaksanaan diskusi rutin Lakpesdam PCNU kota Tasikmalaya.

Teori diskusi kelompok yang dikemukakan oleh M. Atas Semi, mengatakan bahwa sekelompok orang melakukan kegiatan penyampaian pesan. Dalam kegiatan diskusi kelompok ini, orang-orang tersebut saling bertukar pikiran antara satu dengan yang lainnya, mengenai topik permasalahan yang telah disepakati sebelumnya. Pada teori tersebut, Semi mengatakan bahwa ada "sekelompok orang menyampaikan pesan", artinya ada lebih dari satu orang yang menjadi narasumber. Sedangkan pada diskusi rutin Lakpesdam PCNU kota Tasikmalaya, yang menyampaikan pesan atau materi diskusi hanya satu orang narasumber.

Diskusi forum yang dikemukakan oleh Machendrawaty dan Kusnawan mengatakan bahwa diskusi forum merupakan kegiatan ceramah umum atau pertemuan umum yang dilakukan oleh beberapa orang, namun dapat juga dihadiri oleh pengunjung yang kehadirannya tersebut tidak terkait dengan forum, bahkan tidak menutup kemungkinan pengunjung tersebut tidak terlalu memahami permasalahan yang tengah dibicarakan dalam forum tersebut. Forum adalah suatu bagian dari sebuah pertemuan diskusi dimana seluruh kelompok yang hadir dapat mengikutinya. Forum ini berlangsung seusai sebuah 'kelompok kecil' tampil diatas podium. Akan tetapi, meskipun sebenarnya forum tersebut menghendaki partisipasi dari semua orang yang hadir, pada tataran praktisnya hanya sedikit pertukaran pendapat yang terjadi secara horizontal dengan hadirin. Akan tetapi komentar-komentar yang dikemukakan di dalam forum tetap ditujukan bagi semua orang yang hadir.(Wahyudin, 2014)

Pada teori tersebut, Machendrawati dan Kusnawan mengatakan bahwa forum dilakukan setelah 'kelompok kecil' tampil diatas podium. Artinya, forum juga menghendaki narasumber yang lebih dari satu orang. Hal ini berbeda dengan pelaksanaan diskusi rutin yang dilakukan oleh Lakpesdam PCNU kota Tasikmalaya, dimana hanya ada satu orang narasumber, dan juga tidak terdapat podium yang disediakan, melainkan hanya dilakukan dengan cara duduk lesehan, baik peserta diskusi maupun narasumber.

Diskusi Panel menurut Zelko, merupakan kegiatan diskusi yang mana pesertanya diatur oleh peraturan yang sebelumnya telah disepakati. Dalam diskusi panel ini, terdapat beberapa orang yang menjadi pembicara pokok (panelis). Para panelis ini masing-masing akan berbicara tentang masalah yang sama, namun dengan sudut pandang keahlian masing-masing panelis yang berbeda. Dalam kegiatan diskusi panel, biasanya peserta diskusi duduk menghadap meja yang disimpan didepan ruangan pertemuan, dimana moderator dan para panelis duduk dibalik meja tersebut, berhadapan dengan peserta diskusi. Kegiatan pertukaran pendapat dalam diskusi panel, biasanya berlangsung secara informal, bahkan sering kali terjadi tanpa persiapan sama sekali, meskipun kegiatan tersebut berlangsung sesuai dengan peraturan yang disepakati sebelumnya.

Meskipun dalam teori yang diskusi panel yang dikemukakan oleh Zelko ini mengatakan bahwa diskusi panel berlangsung secara tidak formal, namun tetap saja kegiatan diskusi panel menurut Zelko mesti terdapat lebih dari satu narasumber saja. Berbeda dengan diskusi Lakpesdam PCNU kota Tasikmalaya, yang mesti sama-sama berjalan tidak formal, akan tetapi yang bertindak sebagai narasumber hanya satu orang saja.

Adapun diskusi simposium merupakan sebuah pertemuan yang dihadiri oleh orang-orang yang ahli dalam suatu bidang yang sama, guna membahas suatu penemuan atau hasil penelitian dalam bidang tersebut. Kegiatan simposium sejatinya lebih mirip dengan rapat terbuka, yang didalamnya terdapat beberapa pidato dari para ahli tersebut. Pidato yang dikemukakan biasanya terintegrasi dan terarah untuk memecahkan suatu permasalahan guna mencapai tujuan bersama. 
Teori ini juga tidak sejalan dengan pelaksanaan diskusi rutin Lakpesdam PCNU kota Tasikmalaya. Hal ini disebabkan karena, materi yang dibahas dalam kegiatan diskusi rutin Lakpesdam PCNU kota Tasikmalaya ini bukan merupakan hasil penelitian, melainkan hanya merupakan respon dari fenomenafenomena yang terjadi baik bersifat lokal, nasional, maupun internasional.

Teori seminar yang dikemukakan oleh Ahmadi, mengatakan bahwa seminar adalah kegiatan pertemuan guna memberi dan mendiskusikan sebuah informasi. Kegiatan seminar juga biasa diartikan sebagai pertemuan sekelompok orang yang memiliki keahlian dalam bidang yang sama, untuk membahas satu topik permasalahan atau lebih. Kegiatan seminar biasanya membahas permasalahan yang telah disajikan dalam bentuk makalah dan dipimpin oleh seorang moderator. Persentasi makalah tersebut biasanya diiringi dengan adanya pembahasan dari narasumber terkait permasalahan yang disajikan. Selain itu, kegiatan tanya jawab antara peserta dan narasumber juga ikut mewarnai kegiatan seminar.

Teori ini juga tidak sejalan dengan pelaksanaan diskusi rutin Lakpesdam PCNU kota Tasikmalaya. Pada teori seminar, diharuskan adanya makalah yang dibagikan kepada seluruh peserta diskusi, sebelum kegiatan seminar tersebut dilaksanakan. Hal tersebut tidak terjadi pada diskusi rutin Lakpesdam PCNU kota Tasikmalaya, karena pada pelaksanaannya, Lakpesdam tidak membagikan makalah kepada peserta terlebih dahulu.

Teori diskusi pro-kontra ialah terbentuknya suatu kelompok-yang diciptakan dengan sengaja atau tidak- yang menyetujui suatu pendapat atau gagasan, serta kelompok lain yang bertentangan dengan kelompok yang pertama. Jenis Pro-Kontra ini berguna untuk melatih kepekaan dan pemikiran peserta. Yang menjadi topik pembahasana pada jenis ini biasanya topik yang bersifat kontoversi.

Pada teori ini juga, tidak ada keselarasan dengan pelaksanaan diskusi rutin di Lakpesdam PCNU kota Tasikmalaya. Teknis diskusi rutin Lakpesdam PCNU kota Tasikmalaya tidak sengaja membentuk kelompok pro dan kelompok yang kontra. Dalam pelaksanaannya pun tidak selamanya terjadi pro-kontra dalam diskusi tersebut. Tak jarang pula kegiatan diskusi rutin Lakpesdam PCNU kota Tasikmalaya ini hanya diisi oleh tanya-jawab antara peserta dan narasumber.

Selanjutnya teori diskusi rembuk sejati, teori jenis cawan ikan, teori diskusi urun pendapat, dan teori buzz group. Keempat teori diskusi ini sama-sama menghendaki untuk memecah peserta diskusi menjadi kelompok-kelompok kecil. Bedanya, diskusi rembuk sejati membagi peserta diskusi menjadi kelompok-kelompok kecil, yang biasanya terdiri dari tiga sampai lima orang. Masing-masing kelompok kecil tersebut diberikan permasalahan untuk kemudian mereka diskusikan. Hasil diskusi kelompok kecil ini kemudian ditukar dengan kelompok lain lalu saling mengomentari antara satu dengan yang lainnya. Sehingga dalam kegiatan ini, terjadilah sebuah pertukaran pemikiran atau pendapat antar kelompo.

Teori cawan ikan membagi peserta diskusi menjadi dua kelompok. Satu kelompok dengan jumlah peserta sedikit (kelompok kecil, satu kelompok lagi dengan jumlah peserta banyak (kelompok besar). Kelompok kecil membuat lingkaran kecil ditengah ruang, serta membahas sebuah topik diskusi. Sedangkan kelompok besar duduk melingkar mengelilingi kelompok kecil serta hanya menyaksikan jalannya diskusi dari kelompok kecil. Namun demikian, kelompok besar juga bisa ikut andil dalam diskusi tersebut dengan cara hanya mengajukan pertanyaan-pertanyaan. Dalam jenis ini, yang bertugas untuk menyimpulkan diskusi hanyalah kelompok kecil saja. Adapun kelompok besar hanya menjadi partisipan dalam diskusi jenis cawan ikan ini.

Sedangkan teori diskusi urun pendapat, membagi masing-masing peserta diskusi kedalam subkelompok, yang asing-masing kelompok terdiri dari 8-12 orang. Setiap sub-kelompok diberikan satu persoalan yang telah ditulis sebelumnya oleh notulen. Pendapat-pendapat yang dikemukakan biasanya 
diungkapkan secara spontanitas, dan biasanya pendapat-pendapat tersebut 10-30\% merupakan pendapat yang orisinal.

Adapun teori buzz group orang-orang (peserta diskusi) yang relatif berjumlah banyak, dibagi kedalam kelompok-kelompok kecil berjumlah 5-8 orang. Kelompok-kelompok kecil tersebut kemudian membentuk lingkaran dan mendiskusikan persoalan yang telah disajikan. Jika diskusi yang dilakukan oleh kelompok-kelompok kecil tersebut telah selesai, maka hasil perdiskusian masing-masing kelompok akan disampaikan pada pertemuan besar. Moderator akan memberikan kesempatan kepada peserta diskusi untuk bertanya atau mengomentari pendapat-pendapat dari masing-masing kelompok kecil tersebut.

Dari teknis pelaksanaan diskusi yang dikemukakan oleh keempat teori diskusi tersebut, jelas tidak ada yang sejalan dengan pelaksanaan diskusi yang dilakukan oleh Lakpesdam PCNU kota Tasikmalaya. Dalam pelaksanaannya, tidak ada kelompok-kelompok kecil yang berembuk mendiskusikan suatu masalah, melainkan langsung membahas permasalahan yang sebelumnya dibahas panjang lebar oleh seorang narasumber.

Teori Jenis kotak surat masuk merupakan suatu jenis diskusi yang menampilkan satu orang atau sekelompok orang untuk mengambil suatu keputusan guna memecahkan sebuah permasalahan. Sementara itu, peserta diskusi lainnya berperan sebagai orang yang mengajukan berbagai permasalahan untuk dipecahkan oleh penentu keputusan. Pelaksanaan diskusi rutin Lakpesdam PCNU kota Tasikmalaya pun tidak sejalan dengan teori diskusi ini, karena tidak ada penentu keputusan dalam kegiatan diskusi rutin yang dilakukan oleh Lakpesdam PCNU kota Tasikmlaya.

Teori diskusi jenis momentum merupakan diskusi yang dilaksanakan dengan sebuah topik utama yang telah dibagi kedalam beberapa sub-topik. Kegiatan diskusi dengan jenis ini, biasanya dilakukan dalam waktu yang sudah ditentukan. Seseorang yang menjadi narasumber menjelaskan sub-topik tersebut dari urutan pertama hingga akhir, sesuai dengan waktu yang sudah ditentukan. Jika topik tersebut telah dibahas dan peserta pun telah mendapatkan kesempatan bertanya, maka narasumber pun harus menjawab pertanyaan tersebut dalam waktu yang sama, sebelum akhirnya melanjutkan pada subtopik berikutnya. Diskusi dengan jenis ini benar-benar sangat mengefektifkan waktu.

Selanjutnya teori diskusi jenis pemeranan. Pada teori ini, para peserta dituntut untuk banyak membaca dan sangat menguasai tentang apa yang akan diperankan oleh mereka. Penghayatan dari para peserta diskusi ini sangat dibutuhkan guna melancarkan proses diskusi tersebut.

Teori diskusi jenis pemeranan ini pun tidak sejalan dengan teknis pelaksanaan diskusi rutin Lakpesdam PCNU kota Tasikmalaya. Pada teknis pelaksanaan diskusi rutinnya, Lakpesdam PCNU kota Tasikmalaya tidak menuntut pemeranan yang dilakukan oleh para peserta diskusi.

Terakhir, teori diskusi foto novellas, dimana kegiatan diskusi ini berlangsung dengan cara menunjukan foto suatu kejadian, baik yang diinginkan ataupun yang tidak diinginkan. Foto-foto yang ditampilkan dalam diskusi ini, dituntut untuk merangsang emosional dan juga harus rasional. Foto-foto tersebut jelas mesti sesuai dengan topik pembahasan yang akan di diskusikan.

Pelaksanaan diskusi rutin Lakpesdam PCNU kota Tasikmalaya pun tidak menampilkan foto-foto apapun. Bahkan, pada kegiatan diskusi rutin ini sangat jarang narasumber yang menggunakan media infocus untuk sekedar menampilkan pointer-pointer diskusi. Kegiatan diskusi rutin Lakpesdam PCNU kota Tasikmalaya selalu dilakukan secara oral saja, tanpa menggunakan aspek visual didalamnya.

Dari berbagai teori diatas, terlihat jelas bahwa pelaksanaan diskusi rutin Lakpesdam PCNU kota Tasikmalaya tidak sejalan dengan teori diskusi jenis apapun. Hal ini membuktikan bahwa kegiatan diskusi rutin yang dilakukan oleh Lakpesdam PCNU kota Tasikmalaya melahirkan jenis diskusi baru yang tidak sesuai dengan teori-teori diskusi yang dikemukakan diatas. Pelaksanaan diskusi rutin di Lakpesdam PCNU 
Khazanah Sosial, Vol. 1 No. 1: 1-14

Metode Diskusi Lembaga Kajian dan Pengembangan Sumberdaya Manusia Nahdlatul Ulama Agi M. Abdul Ghani

kota Tasikmalaya lebih bersifat santai namun tetap terjadi pertukaran pemikiran yang khidmat. Dalam pelaksanaan diskusi rutin ini, para peserta diskusi maupun narasumber lebih bebas dan santai, tidak terlihat formal sama sekali, dimana peserta diskusi bebas memakan makanan dan minuman yang disediakan panitia, bahkan sembari merokok sekalipun. Kegiatan diskusi rutin ini pun tidakmenggunakan fasilitas penunjang lainnya seperti meja, kursi, papan tulis, infocus dan lainnya, melainkan dilakukan secara oral saja, dan duduk lesehan diatas karpet. Satu-satunya fasilitas yang digunakan dalam kegiatan diskusi rutin Lakpesdam PCNU kota Tasikmalaya ini, hanyalah ruangan diskusi itu sendiri.

Selain itu, penarikan kesimpulan yang dilakukan oleh moderator dalam kegiatan diskusi rutin Lakpesdam PCNU kota Tasikmalaya, tidak selalu melahirkan kesepakatan antara peserta diskusi dan narasumber. Maka tidak jarang pula, disamping menyimpulkan hasil perdiskusian, moderator juga menyerahkan kepada peserta untuk menarik kesimpulannya masing-masing.

Dari pemaparan diatas, dapat disimpulkan bahwa, teknis kegiatan diskusi yang dilakukan oleh Lakpesdam PCNU kota Tasikmalaya dilakukan secara bebas dan santai, namun tetap pada koridor pertukaran pemikiran yang serius. Selain itu, kegiatan diskusi Lakpesdam PCNU kota Tasikmalaya juga berjalan secara demokratis, karena pada akhirnya peserta diskusi diberikan otoritas untuk menyimpulkan hasil perdiskusian sendiri.

\section{Cara Mengemukakan Pendapat dari Orang-Orang yang Terlibat dalam Kegiatan Diskusi di Lakpesdam PCNU Kota Tasikmalaya}

Dari notulensi yang dikemukakan pada hasil penelitian diatas, dapat diketahui bagaimana para peserta diskusi menyampaikan pendapatnya. Pada umumnya, dalam kegiatan diskusi yang diselenggarakan oleh Lakpesdam PCNU kota Tasikmalaya, baik pada kegiatan diskusi umum maupun pada kegiatan diskusi rutin, orang-orang yang terlibat dalam diskusi tersebut (peserta dan narasumber) memiliki cara yang sama dalam mengemukakan pendapatnya.

Pada pelaksanaannya, diskusi umum yang dilakukan oleh Lakpesdam PCNU kota Tasikmalaya, dibagi menjadi dua sesi. Pertama, sesi pemaparan, dimana pada sesi ini, narasumber memaparkan materi pembahasannya terlebih dahulu. Pada kegiatan diskusi umum, di sesi ini para peserta dituntut untuk mendengarkan pemaparan dari narasumber. Sesi kedua, adalah sesi tanya-jawab. Pada sesi ini, peserta diberikan kesempatan untuk bertanya, atau mengemukakan pendapatnya. Pertanyaan atau pendapat dari para peserta ini kemudian ditampung oleh moderator, sebelum akhirnya dijawab atau sekedar dikomentari oleh narasumber.

Berbeda dengan pelaksanaan diskusi rutin Lakpesdam PCNU kota Tasikmalaya. Pada diskusi rutini ini, sejatinya hampir sama dengan diskusi umumnya, dimana pelaksanaan diskusi tersebut dibagi menjadi dua sesi, yakni sesi pemaparan dan sesi tanya-jawab. Akan tetapi, ditengah-tengah pemaparan narasumber, sering kali ada peserta yang mengacungkan tangan untuk sekedar bertanya atau bahkan mengemukakan pendapatnya. Dengan kata lain, kegiatan diskusi rutin ini berjalan secara tidak teratur.

Wamy mengatakan, bahwa sebuah kegiatan diskusi mesti terdapat sinergitas antara narasumber dan peserta diskusi (Machendrawaty \& Kusnawan, 2003: 215). Adanya sinergitas antara narasumber dan peserta diskusi ini dimaksudkan untuk menghindari adanya interfensi dari satu pihak terhadap pihak yang lainnya. Oleh sebab itu, kegiatan diskusi seharusnya dilakukan oleh sekelompok orang dengan pengetahuan yang setara. Namun demikian, menurut Munir, kegiatan diskusi tidak mesti dilakukan oleh sekelompok orang yang memiliki pengetahuan setara. Menurutnya, ada kegiatan diskusi yang disebut dengan As-Ilah wa Ajwibah (tanya-jawab) (Munir, 2015: 335-340). Kegiatan tanya-jawab ini pun, menurut Munir, masih dalam kategori diskusi. Hanya saja, kegiatan diskusi seperti ini dilakukan oleh sekelompok 
orang yang pengetahuannya tidak setara. Biasanya, dalam kegiatan diskusi model tanya-jawab ini, narasumber lebih memiliki pengetahuan diatas peserta diskusinya.

Pada pelaksanaan diskusi yang dilakukan oleh Lakpesdam PCNU kota Tasikmalaya, baik diskusi umum maupun diskusi rutin, tidak selalu terjadi tanya-jawab dan tidak pula selalu terjadi sinergitas antara narasumber dan peserta diskusi. Dalam setiap pelaksanaan diskusinya, terkadang terjadi sinergitas, dimana peserta diskusi juga menanggapi pemaparan narasumber serta mengemukakan pendapatnya dengan disertai argumen-argumennya, namun terkadang juga peserta diskusi hanya bertanya kepada narasumber. Dengan kata lain, dalam kegiatan diskusi yang dilakukan oleh Lakpesdam PCNU kota Tasikmalaya, berada ditengah-tengah antara teori yang dikemukakan oleh Machendrawaty dan Kusnawan, dengan teori yang dikemukakan oleh M. Ali Aziz.

Hal itu disebabkan karena peserta diskusi yang hadir dalam kegiatan diskusi yang dilakukan oleh Lakpesdam PCNU kota Tasikmalaya, khususnya kegiatan diskusi rutin, berasal dari golongan yang berbeda. Peserta dari organisasi PMII misalnya, akan lebih cenderung untuk bertanya, daripada mengemukakan pendapat yang berbeda. Hal ini dikarenakan antara PMII dan Lakpesdam memiliki latarbelakang yang sama, yakni Nahdhatul Ulama. Lain halnya dengan peserta yang berasal dari organisasi HIMA Persis. Peserta dari organisasi HIMA Persis lebih cernderung mengemukakan pendapat yang berbeda dengan argumentasi yang berbeda pula, karena latarbelakang HIMA Persis dan Lakpesdam jelas berbeda.

Namun demikian, penyampaian pendapat yang dilakukan oleh para peserta diskusi, tetap harus dilakukan secara argumentatif serta menggunakan rujukan-rujukan yang mapan baik buku-buku kontemporer ataupun kitab-kitab klasik. Maka dari itu, dapat disimpulkan bahwa orang-orang yang terlibat dalam kegiatan diskusi di Lakpesdam PCNU kota Tasikmalaya, mengemukakan pendapatnya secara argumentatif dengan menggunakan buku-buku kontemporer ataupun kitab-kitab klasik.

\section{Permasalahan yang Dikaji dalam Kegiatan Diskusi di Lakpesdam PCNU Kota Tasikmalaya}

Sebagaimana yang dikemukakan pada hasil penelitian diatas, dalam kegiatan diskusi umum, Lakpesdam PCNU kota Tasikmalaya bekerja sama dengan The Wahid Institute. Oleh karena kontrak kerjasama itulah, permasalahan atau materi yang didiskusikan selalu materi atau permasalahan yang di tentukan oleh pihak The Wahid Institute. Materi atau permasalahan tersebut meliputi tentang kebangsaan, pluralisme, kebhinekaan, kebangsaan, dan toleransi. Kegiatan diskusi umum ini pun, hanya dilakukan saat ada kontrak kerjasama dengan The Wahid Institute.

Lain halnya dengan kegiatan diskusi rutin. Pada kegiatan diskusi rutin ini, Lakpesdam PCNU kota Tasikmalaya tidak bekerjasama dengan pihak manapun. Oleh karena tidak adanya kerjasama dengan pihak-pihak luar, permasalahan atau materi yang didiskusikan dalam kegiatan diskusi rutin ini lebih bervariatif. Tidak seperti kajian diskusi umum yang hanya membahas tentang tema-tema bertajuk Pluralisme, Toleransi, Kebhinekaan, Kebangsaan, dan Kemanusiaan (sesuai dengan kajian pokok The Wahid Institute), permasalahan yang dikaji dalam program diskusi rutin Lakpesdam PCNU kota Tasikmalaya lebih variatif dan multi disiplin ilmu, dari mulai membahas pemikiran Islam, filsafat, ekonomi, hingga sosial-politik.

Sejatinya, yang menjadi fokus kajian diskusi rutin Lakpesdam PCNU kota Tasikmalaya, tergantung pada isu-isu yang sedang ramai di khalayak, baik isu lokal, nasional, maupun internasional. Kegiatan kajian diskusi rutin ini lebih terlihat sebagai suatu respon atas fenomena-fenomena yang terjadi dimasyarakat. Orang-orang yang menjadi narasumber pada kegiatan kajian diskusi rutin Lakpesdam PCNU kota 
Tasikmalaya lebih berfariatif, tergantung pada isu apa yang hendak diangkat dalam kegiatan diskusi tersebut. Seperti yang dilakukan pada saat diskusi bulan Desember, Lakpesdam PCNU kota Tasikmalaya mengangkat isu tentang kebocoran anggaran APBD kota Tasikmalaya. Pada kesempatan itu, Ucok Sky Khadafi selaku direktur Center for Budget Analisys (CBA) tampil menjadi narasumber. Pengurus PP Lakpesdam PBNU pun sempat menjadi narasumber dalam program kajian diskusi rutin ini, serta masih banyak lagi narasumber yang didatangkan oleh Lakpesdam PCNU kota Tasikmalaya. Singkatnya, kegiatan kajian diskusi rutin tidak dimonopoli oleh narasumber dari pihak-pihak Lakpesdam PCNU kota Tasikmalaya saja, namun juga dari pihak luar, sesuai dengan kebutuhan diskusi.

Secara teoritik, sebenarnya tidak ada rumusan baku dari para ahli mengenai materi atau permasalahan yang mesti ada dalam kegiatan perdiskusian. Namun demikian, materi atau permasalahan yang didiskusikan mesti mengandung informasi. Akan tetapi, Aziz berpendapat bahwa, jika diskusi dijadikan sebagai metode dakwah, maka materi yang harus didiskusikan pun mesti materi tentang keagamaan.

Secara umum, permasalahan yang dikaji dalam kegiatan diskusi rutin Lakpesdam PCNU kota Tasikmalaya, selalu mengandung permasalahan atau materi tentang keagamaan. Hal ini terlihat dari datadata hasil penelitian, yang diperoleh dari hasil observasi, wawancara, dan dokumentasi, bahwa kegiatan diskusi rutin yang dilakukan oleh Lakpesdam PCNU kota Tasikmalaya dari mulai tanggal 28 Februari 2016 hingga 21 Mei 2017, semua materi atau permasalahan yang didiskusikan mengandung materi mengenai keagamaan.

Dari fakta dilapangan mengenai materi atau permasalahan yang menjadi fokus kajian diskusi dalam kegiatan diskusi rutin Lakpesdam PCNU kota Tasikmalaya, dapat disimpulkan bahwa materi atau permasalahan yang dikaji dalam kegiatan diskusi rutin ini selalu bersifat faktual dan aktual. Hal ini berdasarkan fakta dilapangan, bahwa, kegiatan diskusi rutin Lakpesdam PCNU kota Tasikmalaya merupakn respon dari adanya fenomena yang terjadi dimasyarakat, baik lokal, nasional, maupun internasional.

\section{Tujuan Kegiatan Diskusi di Lakpesdam PCNU Kota Tasikmalaya}

Kegiatan dakwah melalui diskusi akan menjadi lebih hidup, serta pesan dakwah akan lebih dapat dipahami secara lebih mendalam. Pada hakikatnya, kegiatan diskusi merupakan aktivitas pertukaran pendapat yang terjadi diantara beberapa orang secara lisan, membahas permasalahan tertentu dengan teratur, guna mencari sebuah kebenaran.

Sejatinya, tujuan dari aktivitas diskusi sangatalah banyak dan beragam. Akan tetapi, R.C. Kwant merumuskan tujuan diskusi kedalam tiga bagian besar, yakni tujuan diskusi untuk kebutuhan logis, kebutuhan manusiawi, dan kebutuhan diskusi itu sendiri.(Rahardjo, 2011)

Tujuan diskusi untuk kebutuhan logis; dalam hal ini diskusi menjadi tempat konsultasi untuk menambah pengetahuan, mendapatkan informasi, meluaskan pengalaman dan membuka pandangan. Disamping itu, ia menjadi tempat koordinasi karena adanya kontak dan komunikasi.

Tujuan diskusi untuk kebutuhan manusiawai; dalam hal ini diskusi menjadi tempat untuk mendapatkan pengakuan atau penghargaan, menampilkan kelompok atau individu, menyatakan partisipasi, memberikan dan mendapatkan informasi, serta menunjukkan interaksi.

Tujuan diskusi untuk kebutuhan diskusi itu sendiri; dalam hal ini diskusi dapat menjadi tempat bertukar informasi, tempat mempertajam pengertian dan pendapat, ia menjadi tempat konsultasi, dan penggugahan pendapat. Selain itu, diskusi juga menjadi tempat menyiasati, menganalisis, menyelesaikan 
masalaha, memberikan motivasi dan persesuaian, mengembangkan kerjasama, dan meramalkan partisipasi.

Dari pemaparan teori diatas, dapat disimpulkan bahwa tujuan dari kegiatan diskusi adalah untuk menambah pengetahuan, menumbuhkan sifat toleransi dengan menghargai pendapat orang lain, serta menumbuhkan kesepahaman antara pendapat-pendapat yang berbeda. Pada tataran praktisnya, kegiatan diskusi yang dilakukan oleh Lakpesdam PCNU kota tasikmalaya memang dapat menambah pengetahuan, khususnya pada wilayah keagamaan.

Hal ini dapat dilihat dari hasil penelitian yang dipaparkan pada bab sebelumnya, dimana banyak ditemukan materi-materi diskusi Lakpesdam PCNU kota Tasikmalaya yang membahas tentang masalahmasalah keagamaan dengan jawaban yang secara umum sudah terkenal, namun menghasilkan jawaban yang berbeda dengan jawaban pada umumnya. Contohnya pada kegiatan diskusi rutin yang dilaksanakan pada tanggal 27 Maret 2016, tentang hukuman rajam bagi pezina. Hukuman rajam bagi pezina sudah populer dilkalangan masyarakat, khususnya dikalangan kaum santri. Akan tetapi, melalui perdiskusiannya, Lakpesdam PCNU kota Tasikmalaya berkesimpulan untuk tidak menjatuhkan hukuman rajam bagi pezina, dikarenakan masih ada hukuman lain yang lebih pantas dijatuhkan pada seorang pezina, daripada harus mati.

Diskusi rutin pada tanggal 23 April 2017 tentang tafsiran QS. Ali Imran ayat 7 pun mlahirkan pemahaman yang berbeda dengan pemahaman yang saat ini populer. Lakpesdam PCNU kota Tasikmalaya mengambil pendapat Ibn Rusyd yang memindahkan tanda waqaf, sehingga melahirkan tafsiran yang berbeda dengan tafsiran yang populer. Lakpesdam PCNU kota Tasikmalaya berkeyakinan bahwa beberapa orang yang memeiliki pengetahuan mendalam akan mengetahui tafsiran dari ayat-ayat mutasyabihat.

Dari data yang didapat, kegiatan diskusi rutin Lakpesdam PCNU kota Tasikmalaya memang dapat menambah wawasan bagi para peserta diskusinya. Selanjutnya, berdasarkan teori diatas, tujuan lain dari kegiatan diskusi adalah menimbulkan rasa toleransi dengan cara menghargai pendapat-pendapat yang berbeda. Tujuan ini pun sejalan dengan temuan dilapangan bahwa, kegiatan diskusi rutin Lakpesdam PCNU kota Tasikmalaya, juga bertujuan untuk menimbulkan rasa toleransi.

Hal tersebut dapat dibuktikan dari beragamnya latar belakang peserta yang mengikuti kegiatan diskusi Lakpesdam PCNU kota Tasikmalaya. Beragamnya latar belakang peserta diskusi, tentunya melahirkan pula pemahaman yang beragam. Adanya pemahaman yang beragam ini, tidak serta-merta menumbuhkan api kebencian antar peserta diskusi. Melainkan, adanya perbedaan pendapat ini menimbulkan rasa toleransi antar peserta diskusi. Hal ini pula dapat dibuktikan dengan tidak adanya konflik yang muncul usai kegiatan diskusi rutin ini berlangsung.

Akan tetapi, untuk tujuan ketiga dari kegiatan diskusi ini, nampaknya temuan dilapangan tidak sejalan dengan apa yang dikemukakan oleh teori. Secara teoritik, tujuan kegiatan diskusi adalah adanya kesepahaman diantara seluruh pelaku diskusi. Hal ini jelas bertentangan dengan temuan dilapangan, dimana pada kegiatan diskusi rutin Lakpesdam PCNU kota Tasikmalaya, tidak selamanya melahirkan kesepahaman. Hal tersebut disebabkan karena beragamnya latar belakang peserta diskusi yang hadir. Peserta diskusi berlatar belakang PMII, jelas akan bersepaham dengan Lakpesdam PCNU kota Tasikmalaya, karena sama-sama berlatar belakang Nahdhatul Ulama. Akan tetapi, lain halnya dengan peserta diskusi dengan latar belakang HIMA Persis, yang secara kultural saja sudah berbenturan dengan Lakpesdam PCNU kota Tasikmalaya. Kesimpulan-kesimpulan yang dibuat oleh moderator dalam diskusi rutin Lakpesdam PCNU kota Tasikmalaya pun tidak jarang dilemparkan kepada peserta diskusi sendiri. Hal ini dilakukan oleh moderator demi sikap toleransi yang harus selalu terjaga. 
Dari pemaparan diatas, dapat disimpulkan bahwa tujuan dari kegiatan diskusi rutin Lakpesdam PCNU kota Tasikmalaya adalah untuk menambah pengetahuan, menumbuhkan sikap toleransi, namun tidak selalu melahirkan kesepakatan. Hal ini dikarenakan kegiatan diskusi di Lakpesdam PCNU kota Tasikmalaya tidak menginterfensi peserta diskusinya untuk mengikuti satu pemahaman saja, melainkan tetap menjaga bingkai-bingkai perbedaan pendapat diantara para peserta diskusi.

\section{SIMPULAN}

Pada dasarnya proses diskusi yang dilakukan di Lakpesdam PCNU kota Tasikmalaya berlangsung secara demokratis, argumentatif, membahas permasalahan Islam kontemporer yang aktual dan faktual, serta bertujuan untuk menambah pengetahuan dan menumbuhkan rasa toleransi dengan tidak melahirkan keputusan dan kesepakatan yang bersifat mengikat, karena hakikatnya akan diberikan otoritas kepada peserta diskusi. Dalam posisi seperti itu, maka hakikat dari diskusi sebagai metode dakwah yang dikembangkan oleh Lakpesdam PCNU kota Tasikmalaya, lebih sebagai proses mengeksplorasi pengetahuan, sosialisasi ilmu, internalisasi penghayatan dan pemahaman isu-isu keagamaan kontemporer, yang tetap menjaga bingkai-bingkai perbedaan atau ikhtilaf diantara peserta diskusi.

Oleh karena itu, kegiatan diskusi sebagai metode dakwah yang dilakukan oleh Lakpesdam PCNU kota Tasikmalaya, dapat menjadi model alternatif dakwah dalam pengembangan keilmuan. Metode diskusi ini pada hakikatnya dapat digunakan dalam koridor sebagai proses untuk mengeksplorasi pengetahuan, sosialisasi ilmu, internalisasi penghayatan dan pemahaman isu-isu keagamaan kontemporer, yang tetap menjaga bingkai-bingkai perbedaan atau ikhtilaf diantara peserta diskusi. Sebab jika kegiatan diskusi berusaha menggiring para peserta diskusi untuk menyepakati satu kesepakatan saja, tanpa menampung keragaman pendapat dari para peserta diskusi, maka kegiatan tersebut bukan merupakan kegiatan diskusi, serta tidak akan efektif dijadikan sebagai metode dakwah.

Kegiatan diskusi sebagai metode dakwah pada hakikatnya menuntut para peserta diskusi untuk bersikap toleransi, dengan cara menghargai perbedaan pendapata di antara seluruh peserta diskusi. Oleh karena itu, sudah sepantasnya kegiatan diskusi berjalan secara demokratis tanpa adanya interfensi dari pihak-pihak tertentu.

\section{DAFTAR PUSTAKA}

Al-Mubarakfury, S. (2013). Shahih Sirah Nabawiyah. Bandung: Jabal.

Ardianto, E. (2010). Metodologi Penelitian: untuk Public Relations Kualitatif dan Kuantitatif. Bandung: Simbiosa Rekatama Media.

Aziz, M. A. (2012). Ilmu Dakwah. Jakarta: Kencana.

Basit, A. (2013). Filsafat Dakwah. Depok: Rajagrafindo Persada.

Hotman, A. I. I. \& P. (2011). Filsafat Dakwah: Rekayasa Membangun Agama dan Peradaban Islam. Jakarta: Kencana.

Moleong, L. J. (2012). Metodologi Penelitian Kualitatif. Bandung: Remaja Rosdakarya.

Morissan. (n.d.). Teori Komunikasi. Bogor: Ghalia Indonesia.

Munir, M. (2015). Metode Dakwah. Jakarta: Prenamedia Group.

Rahardjo, T. (2011). Landasan Filosofis Penelitian Komunikasi. Jurnal Semai Komunikasi, 2(1).

Rahman, F. (2010). Islam. Bandung: Pustaka.

Sadiah, D. (2015). Metode Penelitian Dakwah: Pengantar Kualitatif dan Kuantitatif. Bandung: Remaja Rosdakarya.

Wahyudin, Y. (2014). Kiyai Langka dari Cicalengka: Biografi KH. Q. Ahmad Syahid. Bandung: CV. Cahaya 
Khazanah Sosial, Vol. 1 No. 1: 1-14

Metode Diskusi Lembaga Kajian dan Pengembangan Sumberdaya Manusia Nahdlatul Ulama Agi M. Abdul Ghani

Matahari. 